\title{
Toxin profiles of five geographical isolates of Dinophysis spp. from North and South America
}

\author{
Elie Fux ${ }^{\mathrm{a}, *}$, Juliette L. Smith ${ }^{\mathrm{b}}$, Mengmeng Tong ${ }^{\mathrm{b}, \mathrm{c}}$, Leonardo Guzmán ${ }^{\mathrm{d}}$, Donald M. Anderson ${ }^{\mathrm{b}}$ \\ ${ }^{a}$ U.S. Food and Drug Administration, Gulf Coast Seafood Laboratory, 1 Iberville Drive, Dauphin Island, AL 36528, USA \\ b Biology Department, Woods Hole Oceanographic Institution, Woods Hole, MA 02543, USA \\ ${ }^{c}$ College of Environmental Science and Engineering, Nankai University, Tianjin 300071, China \\ ${ }^{\mathrm{d}}$ Instituto de Fomento Pesquero, Balmaceda 252, Puerto Montt, Chile
}

\section{A R T I C L E I N F O}

\section{Article history:}

Received 21 September 2010

Received in revised form 29 November 2010

Accepted 1 December 2010

Available online 10 December 2010

\section{Keywords:}

Dinophysis

Diarrhetic shellfish poisoning

Okadaic acid

Dinophysistoxin

\begin{abstract}
A B S T R A C T
Marine dinoflagellates of the genus Dinophysis can produce toxins of the okadaic acid (OA) and pectenotoxin (PTX) groups. These lipophilic toxins accumulate in filter-feeding shellfish and cause an illness in consumers called diarrhetic shellfish poisoning (DSP). In 2008, a bloom of Dinophysis led to the closure of shellfish harvesting areas along the Texas coast, one of the first DSP-related closures in the U.S. This event resulted in a broad study of toxin production in isolates of Dinophysis spp. from U.S. waters. In the present study, we compared toxin profiles in geographical isolates of Dinophysis collected in the U.S. (Eel Pond, Woods Hole MA; Martha's Vineyard, MA; and Port Aransas Bay, Texas), and in those from Canada (Blacks Harbour, Bay of Fundy) and Chile (Reloncavi Estuary), when cultured in the laboratory under the same conditions. For each isolate, the mitochondrial cox 1 gene was sequenced to assist in species identification. Strains from the northeastern U.S. and Canada were all assigned to Dinophysis acuminata, while those from Chile and Texas were most likely within the $D$. acuminata complex whereas precise species designation could not be made with this marker. Toxins were detected in all Dinophysis isolates and each isolate had a different profile. Toxin profiles of isolates from Eel Pond, Martha's Vineyard, and Bay of Fundy were most similar, in that they all contained OA, DTX1, and PTX2. The Eel Pond isolate also contained OA-D8 and DTX1-D7, and low levels (unconfirmed structurally) of DTX1-D8 and DTX1-D9. D. acuminata from Martha's Vineyard produced DTX1-D7, along with OA, DTX1, and PTX2, as identified in both the cells and the culture medium. D. acuminata from the Bay of Fundy produced DTX1 and PTX2, as found in both cells and culture medium, while only trace amounts of OA were detected in the medium. The Dinophysis strain from Texas only produced OA, and the one from Chile only PTX2, as confirmed in both cells and culture medium.
\end{abstract}

Published by Elsevier Ltd.

\section{Introduction}

Diarrhetic shellfish poisoning (DSP) is a human illness caused by the consumption of shellfish contaminated with toxins of the okadaic acid (OA) group (Yasumoto et al., 1978; Murata et al., 1982). The OA group includes OA,

\footnotetext{
* Corresponding author.

E-mail address: eliefux@hotmail.com (E. Fux).
}

initially isolated from the sponge Halichondria okadaii from which it gets its name (Tachibana and Scheuer, 1981), and the dinophysistoxins DTX1 (Murata et al., 1982) and DTX2 (Hu et al., 1992a). The OA group also includes a sub-group of compounds collectively referred to as the OA diol-esters. This sub-group, resulting from acylation of the OA carboxyl group with various unsaturated diols, was discovered in cultures of Prorocentrum lima (Yasumoto et al., 1989; Hu et al., 1992b; Norte et al., 1994;Fernandez et al., 2003) and of Pagophyllum maculosum (Hu et al., 1992b). These allylic 
diol-esters appear to be derived from enzymatic hydrolysis of longer chain sulfated esters named DTX4 and DTX5 (Hu et al., 1995a,b) through the action of esterases in the Prorocentrum cell (Quilliam et al., 1996; Windust et al., 1997). DTX4 is a water-soluble sulfated ester derivative of OA, initially isolated from $P$. lima culture (Hu et al., 1995a). This was followed by the discovery of the sulfated esters DTX5a and DTX5b in a culture of P. maculosum (Hu et al., 1995b), and DTX5c from a culture of Prorocentrum belizeanum (Cruz et al., 2006). Cruz and co-workers suggested that different phytoplankton species can be associated with the production of specific enol esters and that sulfate derivatives of each reported diol-ester exist. In addition to diol-esters, a C8-triol OA derivative was more recently observed in seawater collected during a Dinophysis bloom in Norway (Torgersen et al., 2008a).

OA, DTX1, and DTX2 undergo bio-transformation reactions in shellfish yielding DTX3, a generic denomination for all 7-O-acyl fatty acid esters. Esterification can occur with a wide range of fatty acid esters from $C_{14}$ to $C_{22}$ with unsaturation number up to 6 , which often leads to a complex toxin profile (Yasumoto et al., 1985; Marr et al., 1992; Torgersen et al., 2008b). Furthermore, fatty acid esters resulting from the bio-transformation of OA diol-esters were recently discovered in mussels, and include those of the 7$\mathrm{OH}$ of the OA moiety and of the $\mathrm{OH}$ group of the diol moiety (Torgersen et al., 2008a). The structures of the compounds belonging to the OA group are shown in Fig. 1. In addition to toxins from the OA group, Dinophysis also produces pectenotoxin-2 (Yasumoto et al., 1985; Lee et al., 1989). Pectenotoxins (PTX) are macrocyclic polyethers with different toxicological properties than toxins from the OA group.

The occurrence of Dinophysis spp., especially Dinophysis acuta, D. acuminata and Dinophysis fortii, have been linked to the accumulation of OA group toxins and DSP in Asia (Yasumoto et al., 1978; Mak et al., 2005), North America (Subba Rao et al., 1993; Campbell et al., 2010), South America (Zhao et al., 1993; Garcia et al., 2004), Australasia (MacKenzie et al., 1998, 2002; Madigan et al., 2006), North of Europe (Torgersen et al., 2005; Turrell and Stobo, 2007; Fux et al., 2009) and South of Europe (Boni et al., 1993; Reguera et al., 1993; Gago-Martinez et al., 1993; Mouratidou et al., 2006). DSP symptoms include nausea, vomiting, diarrhea, and abdominal pain. The scientific panel of the European food safety authority has reviewed the toxicological data available for the OA group and toxicity equivalent factors of 1 , 1 and 0.6 were established for OA, DTX1 and DTX2, respectively (Anonymous, 2008). PTXs are not diarrhetic toxins but are hepatotoxic when administered intraperitoneally (Aune, 1997). More research into the toxicology and mechanism of action of PTXs is necessary but because they are much less toxic to mice when administered orally than intraperitoneally, PTXs may be of less concern to public health than was previously supposed (Miles, 2007).

In February 2008, a toxin-producing bloom of Dinophysis was documented for the first time in the Gulf of Mexico, resulting in a shellfish harvesting closure (Campbell et al., 2010). This event led to a study of the potential for DSP toxin production by Dinophysis spp. in North America. Here we compare the production of OA and PTX analogues in five isolates of Dinophysis from North and South America. All species were cultured in the laboratory under the same conditions, and the cells and the media were collected and extracted separately for LC-MS/MS analyses.

\section{Methods}

\subsection{Isolation and culture conditions}

Five isolates of Dinophysis were examined. An uni-algal, multi-cell culture from Eel Pond in Woods Hole, Massachusetts, USA (DAEP01) was established in September 2006 $\left(\sim 41.5^{\circ} \mathrm{N}, 70.6^{\circ} \mathrm{W}\right)$. The other four stains were all derived from single-cell isolations from water samples. Two strains were collected in March 2008, from the Port of Aransas Bay (DAPA01), Texas, USA $\left(\sim 27.8^{\circ} \mathrm{N}, 97.1^{\circ} \mathrm{W}\right)$ and from the Reloncavi Estuary (DARE01), Chile $\left(\sim 41.42^{\circ} \mathrm{S}, 72.26^{\circ} \mathrm{W}\right)$. The two other strains were collected in August, 2008, from coastal waters south of Martha's Vineyard (DAMV01), Massachusetts, USA $\left(\sim 41.0^{\circ} \mathrm{N}, 70.5^{\circ} \mathrm{W}\right)$ and from Blacks Harbour, Bay of Fundy (DABOF01), Canada $\left(\sim 45.05^{\circ} \mathrm{N}\right.$, $66.78^{\circ} \mathrm{W}$ ), respectively. A detailed description of isolation methods is contained in Tong et al. (in press). In brief, the individual Dinophysis cells were isolated into separate wells of a 48-well tissue culture plate and fed with a clean Myrionecta rubra cell suspension (CCMP2563) which had been previously raised on Geminigera cryophila (CCMP2564) following the protocols of Park et al. (2006) as modified by Hackett et al. (2009). Once the Dinophysis culture was established, the cultures were transferred to 1-L flasks and the ciliate was fed to Dinophysis weekly in a 5:1 ratio of prey:predator. All the cultures were maintained at $6{ }^{\circ} \mathrm{C}$ in modified f/2-Si medium (Anderson et al., 1994) in dim light (65 $\mu \mathrm{mol}$ photons $\cdot \mathrm{m}^{-2} \mathrm{sec}^{-1}$ ) under a $14 \mathrm{~h}$ light: $10 \mathrm{~h}$ dark photocycle. Cells were collected for extraction and subsequent analyses for DSP toxin during plateau phase. The colder temperatures used in these experiments were necessary because of the physiological tolerances of the Myrionecta and Geminigera isolates.

\subsection{PCR-amplification and DNA sequencing}

For species identification, DNA sequencing was conducted on each isolate. A subsample $(1.5 \mathrm{~mL})$ of each culture was transferred to a sterile micro-centrifuge tube and centrifuged for $2 \mathrm{~min}$ at $12,000 \times \mathrm{g}$. Supernatant was removed until only the pellet and ca. $250 \mu$ l of supernatant remained. Pellets were extracted for DNA as per manufacturer specifications using the Generation Capture Column Kit (Qiagen, Valencia, CA) and stored at $-20{ }^{\circ} \mathrm{C}$ until PCR amplification.

Amplifications were performed in an Eppendorf PCR cycler with the primers Dinocox1R and Dinocox1F (Lin et al., 2002; Integrated DNA Technologies). PCR reaction mixtures $(25 \mu \mathrm{l})$ included $1.25 \mu \mathrm{l}$ of each primer $(10 \mu \mathrm{M})$, $2.0 \mu \mathrm{l}$ of $\mathrm{MgCl}_{2}$ (25 mM), $2.5 \mu \mathrm{l}$ of $\operatorname{dNTP}(8 \mathrm{mM})$ and $10 \times$ PCR buffer, $14.5 \mu \mathrm{l}$ of nuclease-free water, $0.125 \mu \mathrm{l}$ of DNA polymerase ( 5 units $/ \mu 1$, AmpliTaq DNA Polymerase, Roche Molecular Systems), and $1 \mu$ l of DNA template. The cycle included denaturation at $94^{\circ} \mathrm{C}$ for $10 \mathrm{~min}$, followed by 40 cycles at $94{ }^{\circ} \mathrm{C}$ for $1 \mathrm{~min}, 55^{\circ} \mathrm{C}$ for $1 \mathrm{~min}$, and $72{ }^{\circ} \mathrm{C}$ for $3 \mathrm{~min}$, ending with $10 \mathrm{~min}$ at $72^{\circ} \mathrm{C}$ (Raho et al., 2008). 


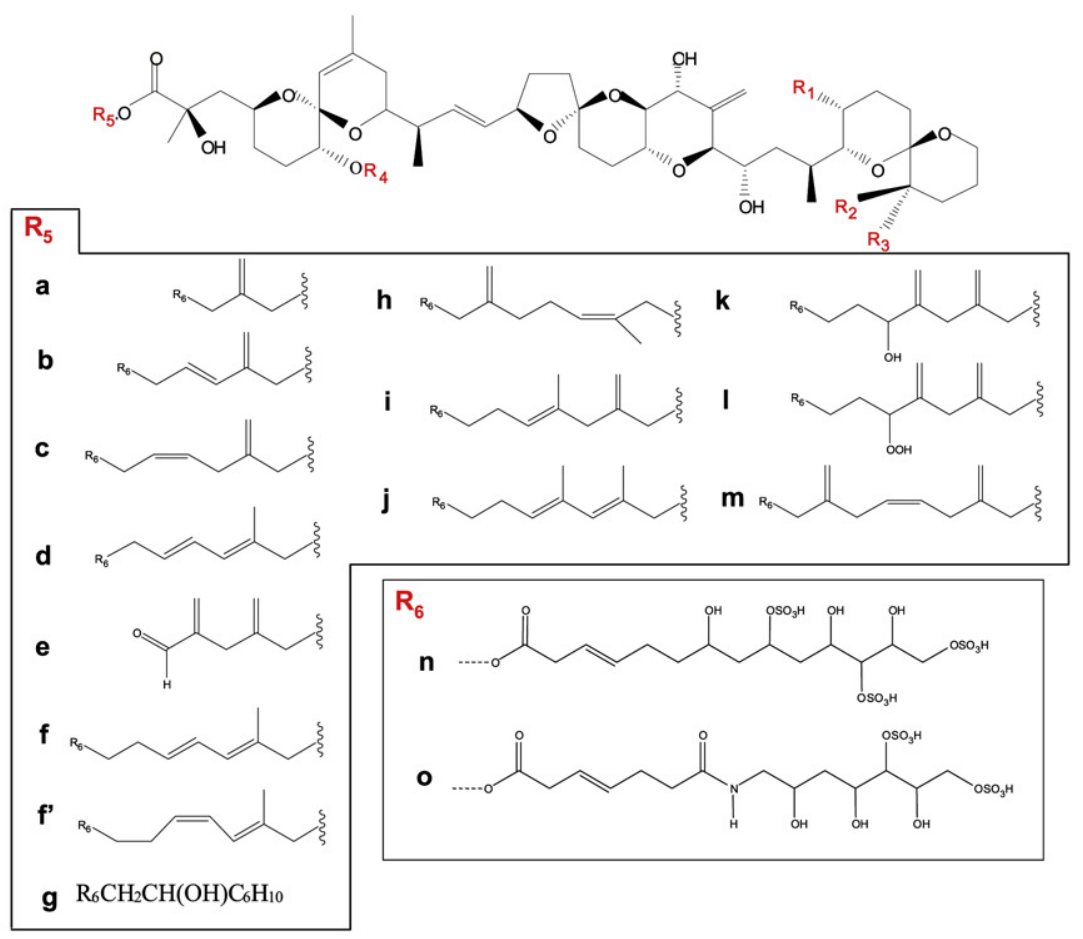

\begin{tabular}{|c|c|c|c|c|c|c|c|c|}
\hline Toxin name & $\mathbf{R}_{1}$ & $\mathbf{R}_{2}$ & $\mathbf{R}_{3}$ & $\mathbf{R}_{4}$ & $\mathbf{R}_{5}$ & $\mathbf{R}_{6}$ & Mw & Ref \\
\hline $\mathrm{OA}$ & $\mathrm{CH}_{3}$ & $\mathrm{H}$ & $\mathrm{H}$ & $\mathrm{H}$ & $\mathrm{H}$ & - & 804.5 & (1) \\
\hline DTX1 & $\mathrm{CH}_{3}$ & $\mathrm{CH}_{3}$ & $\mathrm{H}$ & $\mathrm{H}$ & $\mathrm{H}$ & - & 818.5 & $(2,3)$ \\
\hline DTX2 & $\mathrm{H}$ & $\mathrm{H}$ & $\mathrm{CH}_{3}$ & $\mathrm{H}$ & $\mathrm{H}$ & - & 804.5 & $(2,3)$ \\
\hline DTX3 & $\mathrm{H}$ or $\mathrm{CH}_{3}$ & $\mathrm{H}$ or $\mathrm{CH}_{3}$ & $\mathrm{H}$ or $\mathrm{CH}_{3}$ & Acyl & $\mathrm{H}$ & - & $1012-1097$ & $(4,5)$ \\
\hline DTX4 & $\mathrm{CH}_{3}$ & $\mathrm{H}$ & $\mathrm{H}$ & $\mathrm{H}$ & $\mathrm{f}$ & $\mathrm{n}$ & 1470.6 & (6) \\
\hline DTX5a & $\mathrm{CH}_{3}$ & $\mathrm{H}$ & $\mathrm{H}$ & $\mathrm{H}$ & d & o & 1390.6 & (7) \\
\hline DTX5b & $\mathrm{CH}_{3}$ & $\mathrm{H}$ & $\mathrm{H}$ & $\mathrm{H}$ & $\mathrm{f}$ & o & 1404.6 & (7) \\
\hline DTX 5c & $\mathrm{CH}_{3}$ & $\mathrm{H}$ & $\mathrm{H}$ & $\mathrm{H}$ & $\mathrm{m}$ & 0 & 1431.1 & (8) \\
\hline $\mathrm{C}_{4}$-diol OA & $\mathrm{CH}_{3}$ & $\mathrm{H}$ & $\mathrm{H}$ & $\mathrm{H}$ & $\mathrm{a}$ & $\mathrm{OH}$ & 874.6 & (9) \\
\hline $\mathrm{C}_{6}$-diol OA & $\mathrm{CH}_{3}$ & $\mathrm{H}$ & $\mathrm{H}$ & $\mathrm{H}$ & b & $\mathrm{OH}$ & 900.6 & (10) \\
\hline $\mathrm{C}_{7}$-diol OA & $\mathrm{CH}_{3}$ & $\mathrm{H}$ & $\mathrm{H}$ & $\mathrm{H}$ & c & $\mathrm{OH}$ & 914.6 & (11) \\
\hline $\mathrm{C}_{7}$ diol OA & $\mathrm{CH}_{3}$ & $\mathrm{H}$ & $\mathrm{H}$ & $\mathrm{H}$ & d & $\mathrm{OH}$ & 914.6 & (12) \\
\hline DTX6 & $\mathrm{CH}_{3}$ & $\mathrm{H}$ & $\mathrm{H}$ & $\mathrm{H}$ & $\mathrm{e}$ & - & 912.6 & (13) \\
\hline $\mathrm{C}_{8}$-diol OA & $\mathrm{CH}_{3}$ & $\mathrm{H}$ & $\mathrm{H}$ & $\mathrm{H}$ & $\mathrm{f}$ & $\mathrm{OH}$ & 928.6 & (12) \\
\hline cis- $\mathrm{C}_{8}$-diol OA & $\mathrm{CH}_{3}$ & $\mathrm{H}$ & $\mathrm{H}$ & $\mathrm{H}$ & $f^{\prime}$ & $\mathrm{OH}$ & 928.6 & (14) \\
\hline $\mathrm{C}_{8}$-triol OA & $\mathrm{CH}_{3}$ & $\mathrm{H}$ & $\mathrm{H}$ & $\mathrm{H}$ & g & $\mathrm{OH}$ & 946.6 & (15) \\
\hline $\mathrm{C}_{9}$-diol OA & $\mathrm{CH}_{3}$ & $\mathrm{H}$ & $\mathrm{H}$ & $\mathrm{H}$ & $\mathrm{h}$ & $\mathrm{OH}$ & 942.6 & (11) \\
\hline $\mathrm{C}_{9}$-diol OA & $\mathrm{CH}_{3}$ & $\mathrm{H}$ & $\mathrm{H}$ & $\mathrm{H}$ & $\mathrm{i}$ & $\mathrm{OH}$ & 942.6 & (12) \\
\hline $\mathrm{C}_{9}$-diol OA & $\mathrm{CH}_{3}$ & $\mathrm{H}$ & $\mathrm{H}$ & $\mathrm{H}$ & $\mathrm{j}$ & $\mathrm{OH}$ & 942.6 & (16) \\
\hline $\mathrm{C}_{9}$-triol OA & $\mathrm{CH}_{3}$ & $\mathrm{H}$ & $\mathrm{H}$ & $\mathrm{H}$ & $\mathrm{k}$ & $\mathrm{OH}$ & 958.6 & (10) \\
\hline $\begin{array}{l}\mathrm{C}_{9} \text {-hydro- } \\
\text { peroxy-diol OA }\end{array}$ & $\mathrm{CH}_{3}$ & $\mathrm{H}$ & $\mathrm{H}$ & $\mathrm{H}$ & 1 & $\mathrm{OH}$ & 974.6 & (10) \\
\hline $\mathrm{C}_{10}$-diol OA & $\mathrm{CH}_{3}$ & $\mathrm{H}$ & $\mathrm{H}$ & $\mathrm{H}$ & $\mathrm{m}$ & $\mathrm{OH}$ & 954.6 & $(10)$ \\
\hline
\end{tabular}

Fig. 1. Structures of the characterized analogues of okadaic acid. From:(1) Tachibana and Scheuer, 1981; (2) Murata et al., 1982; (3) Larsen et al., 2007; (4) Yasumoto et al., 1985; (5) Marr et al., 1992 (6) Hu et al., 1995a; (7) Hu et al., 1995b; (8) Cruz et al., 2006; (9) Fernandez et al., 2003; (10) Suarez-Gomez et al., 2005; (11) Yasumoto et al., 1989; (12) Hu et al., 1992a; (13) Suarez-Gomez et al., 2001; (14) Miles et al., 2006; (15) Torgersen et al., $2008 \mathrm{a}$; (16) Norte et al., 1994.

Amplification was confirmed using 1\% aragose gels stained with ethidium bromide and UV-transilumination. Sequencing was performed by Eurofins MWG Operon (Huntsville, $\mathrm{AL}$ ). Sequences were aligned using Sequencher Software (Gene Codes Corporation, Ann Arbor, MI) and compared to sequences in GenBank using the Basic Local Alignment Search Tool (BLAST) algorithms.

\subsection{Sample preparation and extraction of toxins}

Dinophysis cells $(\sim 1,000,000)$ were separated from medium using a $13-\mu \mathrm{m}$ sieve ( $4 \mathrm{~cm}$ diam.). The sieved cells and filtrate were treated separately. The cells were rinsed on the sieve with fresh $\mathrm{f} / 2$ media, and kept wet to minimize breakage. The cells were washed into a $15-\mathrm{mL}$ Falcon tube 
using fresh $\mathrm{f} / 2$ media $(13 \mathrm{~mL})$, and the tube immersed in a water bath at $100{ }^{\circ} \mathrm{C}$ for $5 \mathrm{~min}$. The samples were frozen at $-20{ }^{\circ} \mathrm{C}$, thawed at room temperature, and sonicated in a water bath (Fisher ultrasonic cleaner, Model FS30H) for 15 min before solid-phase extraction (SPE). The SPE cartridges (Oasis HLB, $60 \mathrm{mg}$; Waters, Milford, MA) were conditioned with methanol ( $3 \mathrm{~mL}$ ) and Milli-Q water ( $3 \mathrm{~mL}$ ). The cells were loaded on the stationary phase at a flow rate of $\sim 1 \mathrm{~mL} / \mathrm{min}$. The cartridges were washed with Milli-Q water $(6 \mathrm{~mL})$ and eluted with methanol $(1 \mathrm{~mL})$ into 1.5-mL high recovery LC vials (Suzuki et al., 2008; Miles et al., 2004a). The extracts were stored at $-20^{\circ} \mathrm{C}$.

After initial sieving, the filtrate was immediately loaded onto an Oasis HLB SPE cartridge $(60 \mathrm{mg})$ that was equilibrated as described above, washed with $3 \mathrm{~mL}$ of Milli-Q water, and eluted with $1 \mathrm{~mL}$ of $100 \% \mathrm{MeOH}$ into a glass $1.5-$ $\mathrm{mL}$ high recovery $\mathrm{LC}$ vial and stored at $-20^{\circ} \mathrm{C}$. Eluates from the cell and filtrate samples were heated at $40^{\circ} \mathrm{C}$ in a heating block, dried under a stream of $\mathrm{N}_{2}$ and re-suspended in $0.5 \mathrm{~mL}$ and $0.3 \mathrm{~mL}$ of $\mathrm{MeOH}$, respectively, for LC-MS/MS analysis.

\subsection{Liquid-chromatography mass spectrometry detection}

LC-MS/MS system consisted of an Agilent 1100 HPLC with binary pumping system and autosampler coupled to an API4000 mass spectrometer (PE-SCIEX, Concorde, ON) with a Turbo Spray interface. Separation of the toxins was achieved on a Thermo Hypersil C8 column $(50 \times 2.1 \mathrm{~mm}$; $3 \mu \mathrm{m}$ particle size) maintained at $40^{\circ} \mathrm{C}$ and equipped with a $10 \mathrm{~mm}$ guard column of the same stationary phase. Gradient elution was performed at a flow rate of $0.25 \mathrm{~mL} /$ min. Mobile phase consisted of acetonitrile (ACN) and water containing $0.1 \%$ acetic acid. Gradient was initiated at $30 \% \mathrm{ACN}$, increasing to $100 \% \mathrm{ACN}$ at $9 \mathrm{~min}$, and held for $3 \mathrm{~min}$ before returning to initial conditions, and re-equilibrated for 9 min prior to the next injection.

All compounds were analyzed in the positive ionization mode using selected reaction monitoring (SRM). OA and DTX1 were monitored using their protonated molecules $[\mathrm{M}+\mathrm{H}]^{+}$as precursor ions and the transitions $\mathrm{m} / \mathrm{z}$ $805.5 \rightarrow 223.4$ and $819.5 \rightarrow 237.4$, respectively. The diolesters of OA and DTX1 were monitored using their ammonium adducts $\left[\mathrm{M}+\mathrm{NH}_{4}\right]^{+}$as the precursor ions, and transition ions of $\mathrm{m} / \mathrm{z} 223.4$ and 237.4, respectively. Precursor ions for the diol-esters of OA included $m / z$ 918.6, 932.6, 946.6, 960.6, and 974.6, corresponding to the unsaturated $\mathrm{C} 6$ to $\mathrm{C} 10$ diols. The precursor ions corresponding to the diol-esters of DTX1 were $m / z$ 932.6, 946.6, 960.6, 974.6, and 988.6. PTX2 was monitored using the transition $\mathrm{m} / \mathrm{z}$ $876.5 \rightarrow 551.5$, where the ammonium adduct $\left[\mathrm{M}+\mathrm{NH}_{4}\right]^{+}$ was used as the precursor ion. All transitions were monitored using collision energy of $45 \mathrm{eV}$, except for PTX2 where $40 \mathrm{eV}$ was used. Nitrogen heated at $350{ }^{\circ} \mathrm{C}$ was used as nebulizing gas. The entrance potential was set at $80 \mathrm{~V}$ unless otherwise specified.

Fragment and precursor ion scans were used to confirm the identity of some of the compounds. Conditions were the same as described above, except for the collision energy and the entry potential as specified in the results section. DTX4, DTX5, and related compounds, were monitored in the negative ion mode, using the same mobile phase without acetic acid. Full scan spectra were acquired from $m / z 500$ to 900 and from $m / z 900$ to 1500 . Selected transitions were also monitored at a collision energy of $30 \mathrm{eV}$ and a declustering potential (DP) of $80 \mathrm{~V}$. The loss of a sulfate group from DTX4, DTX5a, DTX5b, and DTX5c was monitored using the transitions $1471.6 \rightarrow$ 1391.6, 1391.6 $\rightarrow$ 1311.6, $1405.6 \rightarrow$ 1325.6, and $1429.6 \rightarrow 1349.6$, respectively. Full scan spectra were also acquired in the positive ion mode from $\mathrm{m} / \mathrm{z} 1300$ to 1500 , and the masses corresponding to the sodium and ammonium adducts of DTX4 and DTX5a, b, c were extracted.

Certified standard solutions of OA (CRM-OA-c) and PTX2 (CRM-PTX2) were purchased from the National Research Council (Canada). DTX1 was purchased from Bluebiotek (Germany) as non-certified material.

\section{Results}

\subsection{DNA sequencing}

DNA analysis was used for the species identification of the five isolates. Species within the Dinophysis acuminata complex (D. acuminata, Dinophysis sacculus, and Dinophysis ovum) cannot be distinguished based on the LSU or ITS regions of the ribosomal RNA gene due to minimal variability in these regions (Edvardsen et al., 2003), so Raho et al. (2008) proposed the mitochondrial cox1 gene as a more informative marker. We therefore utilized the Dinocox1F and Dinocox1R primers described by Lin et al. (2002) for the DNA analysis of our five isolates.

Dinophysis isolates from Eel Pond, Martha's Vineyard, and the Bay of Fundy matched D. acuminata (EU130566.1) with $100 \%$ query coverage and $100 \%$ position identification. The isolate from Reloncavi Estuary, Chile, however, matched

Table 1

Summary of the toxin profiles of five Dinophysis isolates as determined by LC-MS/MS

\begin{tabular}{|c|c|c|c|c|c|c|c|c|c|c|c|c|c|c|}
\hline Species & Origin & $\mathrm{OA}$ & OA-D6 & OA-D7 & OA-D8 & OA-D9 & OA-D10 & DTX1 & DTX1-D6 & DTX1-D7 & DTX1-D8 & DTX1-D9 & DTX1-D10 & PTX2 \\
\hline D. acuminata & Eel Pond, USA & $\mathrm{X}$ & nd & nd & $\mathrm{X}$ & nd & nd & $\mathrm{X}$ & nd & $\mathrm{X}$ & $\mathrm{D}$ & $\mathrm{D}$ & nd & $\mathrm{X}$ \\
\hline D. acuminata & $\begin{array}{l}\text { Martha's Vineyard, } \\
\text { USA }\end{array}$ & $\mathrm{X}$ & nd & nd & nd & nd & nd & $\mathrm{X}$ & nd & $\mathrm{X}$ & nd & nd & nd & $\mathrm{X}$ \\
\hline D. acuminata & $\begin{array}{l}\text { Bay of Fundy, } \\
\text { Canada }\end{array}$ & M & nd & nd & nd & nd & nd & $\mathrm{X}$ & nd & nd & nd & nd & nd & $\mathrm{X}$ \\
\hline $\begin{array}{l}\text { D. acuminata } \\
\text { complex }\end{array}$ & $\begin{array}{l}\text { Reloncavi Estuary, } \\
\text { Chile }\end{array}$ & nd & nd & nd & nd & nd & nd & nd & nd & nd & nd & nd & nd & $\mathrm{X}$ \\
\hline $\begin{array}{l}\text { D. acuminata } \\
\text { complex }\end{array}$ & $\begin{array}{l}\text { Gulf of Mexico, } \\
\text { USA }\end{array}$ & $\mathrm{X}$ & nd & nd & nd & nd & nd & nd & nd & nd & nd & nd & nd & nd \\
\hline
\end{tabular}

$\mathrm{X}$ : Present in cells and medium and confirmed by MS/MS; M: Only detected in the medium; D: Compound detected in the SRM trace but not confirmed by MS/MS fragmentation scan; nd: not detected. 
equally with D. ovum (AM931583.2) and D. acuminata (EU130566.1), where in both cases there was 100\% query coverage with the sequences in GenBank and a 99\% match. Similarly, the isolate from the Gulf of Mexico was equally matched with D. acuminata (EU130566.1, EU130565.1) and D. ovum (AM931583.2) with a query coverage of $78 \%$ for the 98-100\% identified positions. According to the DNA analysis, we conclude that the three northeastern North American strains are $D$. acuminata, while the isolates from Chile and the Gulf of Mexico are within the D. acuminata complex but the precise species designations are not discernable with the cox1 marker.

\subsection{Toxin composition}

Toxin composition profiles in the five geographical isolates of Dinophysis are presented in Table 1. In most cases, the same toxins were detected in the cells as in the medium, except for $D$. acuminata from the Bay of Fundy where OA was only detected in the medium. It is likely that
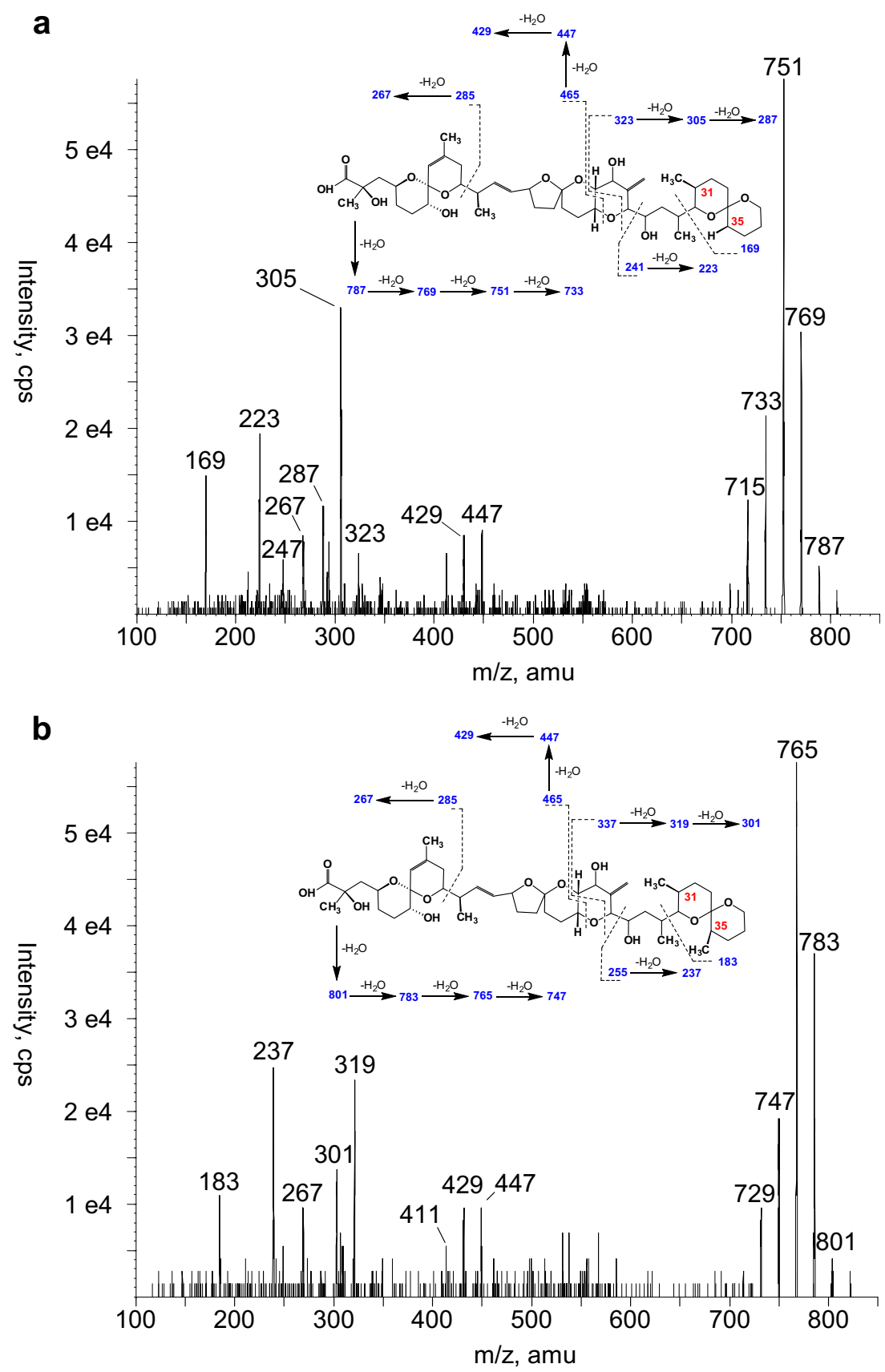

Fig. 2. MS/MS product ion spectra and proposed fragmentation pathways of the protonated molecules of: (a) OA, $m / z$ 805.5, and (b) DTX1 $m / z$ 819.5. 
OA was not detected in the cells because of insufficient biomass.

\subsubsection{D. acuminata isolate from Eel Pond}

The MS/MS spectra of OA (Fig. 2a) was in agreement with the proposed fragmentation pattern of $O A$ in positive ionization mode (Quilliam, 1995; Suzuki et al., 2004), with successive losses of water from the protonated ions of $\mathrm{m} / \mathrm{z}$ $787,769,751,733$, and 715 , and the characteristic fragment ions of $m / z 447,429,305,223$, and 169 . The fragmentation of DTX1 was very similar (Fig. 2b), with several losses of water from the protonated ion $(m / z 801,783,765,747$, and 729 ). The fragments of $m / z 447$ and 429 were common to OA, while those of the right side of the DTX1 molecule were increased by 14 Da due to the additional methyl group at C35 (m/z 319, 301, 237, and 183) as shown in Fig. 2b. An increase of the collision energy from 30 to $45 \mathrm{eV}$ allowed for an increase in the abundance of $m / z 223$ and 237, relative to $m / z 305$ and 319, for OA and DTX1, respectively (data not shown). Therefore, the screening of OA and DTX1, and their corresponding diol-esters, were performed using a collision energy of $45 \mathrm{eV}$. The fragment ions used for $\mathrm{OA}$
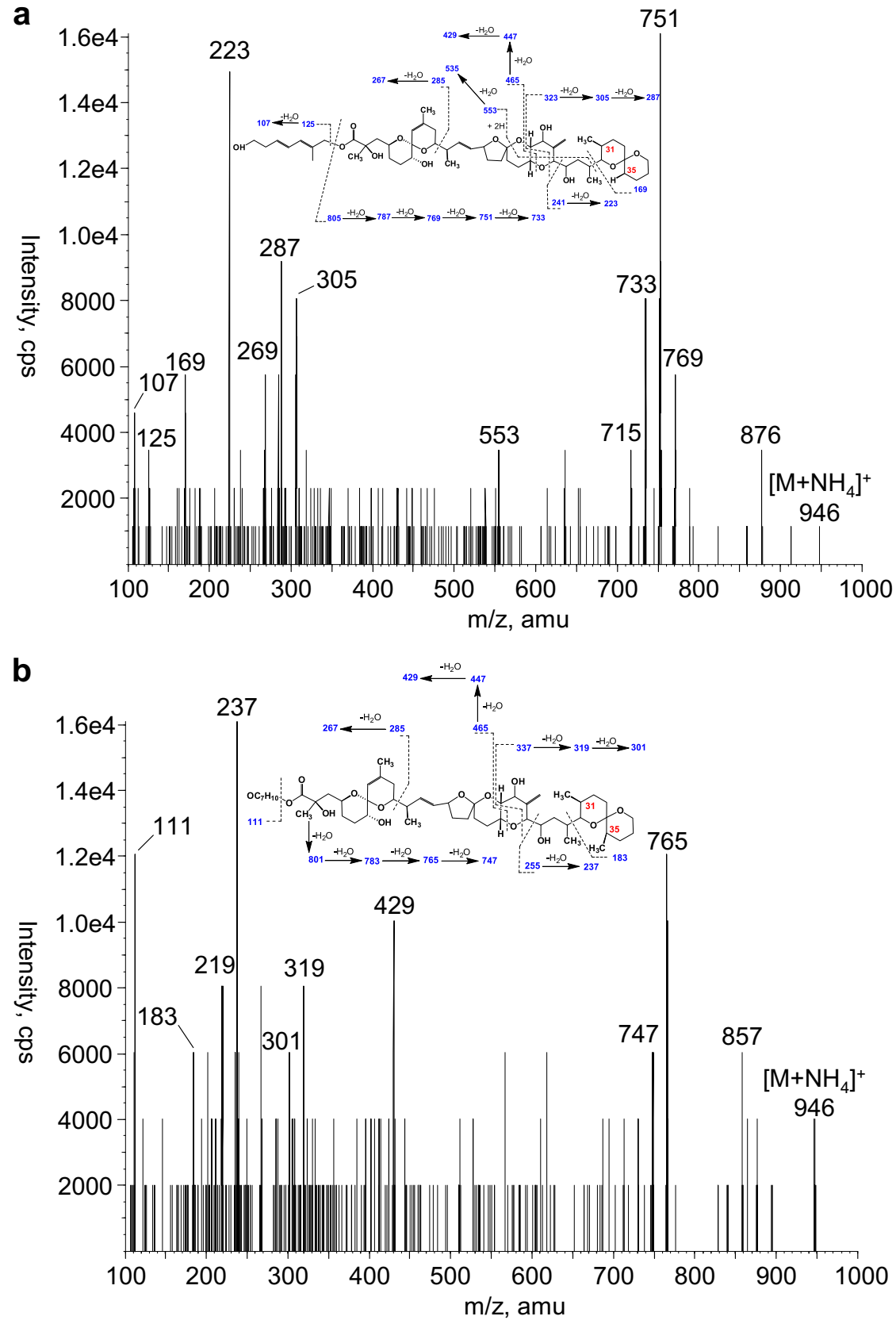

Fig. 3. MS/MS product ion spectra and proposed fragmentation pathways of the ammonium adducts [M $\left.+\mathrm{NH}_{4}\right]^{+}$of: (a) OA-D8, $m / z 946.6$, and (b) DTX1-D7, $m / z$ 946.6 . 
and DTX1 (m/z 223 and 237, respectively) enabled the setting of SRM ion transitions for screening the diol-esters of OA and DTX1 despite the identical masses of some of the precursor ions (e.g., precursors of OA-D8, OA-D9, DTX1-D7, DTX1-D8).

OA was detected in the cells and medium, with the same retention time as that of certified standard (7.75 min). OAD8 was also observed in the $m / z 805 \rightarrow 223$ transition window at $8.69 \mathrm{~min}$ in the cells and the medium, as a result of in-source fragmentation. OA-D8 was detected at the same retention time in the $946 \rightarrow 223$ transition, where the ammonium adduct $\left[\mathrm{M}+\mathrm{NH}_{4}\right]^{+}$was used as the precursor ion. The identity of OA-D8 was confirmed by fragment ion scan with collision energy of $45 \mathrm{eV}$, a DP of $60 \mathrm{~V}$, and Q3 scanning from $m / z 100$ to 900 (Fig. 3a). The fragmentation pattern for OA-D8 was nearly identical to that of OA, with additional ions of $m / z 125$ and 107 corresponding to the C8 diol-ester fragment and its loss of water. The precursor ammonium adduct of $\mathrm{m} / z 946$ was still observed in the OA-D8 fragmentation spectrum (Fig. 3a). The presence of OA-D8 was confirmed in D. acuminata from Eel Pond in our previous study by comparison with an extract of $P$. lima used as reference (Hackett et al., 2009).

DTX1 was detected at $9.0 \mathrm{~min}$ and the most prominent DTX1 diol-ester in cells and media was DTX1-D7, eluting at $9.6 \mathrm{~min}$. The MS/MS product ion spectrum of DTX-D7 is shown in Fig. 3b. Several characteristic fragment ions of DTX1 were observed $(\mathrm{m} / \mathrm{z} 765,747,429,319,301,237,219$, 183 ), as well as an additional fragment of $m / z 111$ corresponding to the charged unsaturated diol with a seven carbon chain. D. acuminata cells from Eel pond also contained DTX1-D8 and DTX1-D9 which were detected in the transitions of $\mathrm{m} / \mathrm{z} 960.6 \rightarrow 237.4$ and $974.6 \rightarrow 237.4$, respectively. Due to the low concentrations of the compounds, fragment ion scan analysis was not possible. The retention times of DTX1, DTX1-D7, and the putative DTX1-D8 and DTX1-D9 compounds, are in agreement with their expected order of elution (i.e., the longer the side chain of the diol-ester, the longer the retention time on the stationary phase). PTX2 was detected in both cells and media of the $D$. acuminata culture, with a retention time of 8.27 min, matching that of the certified standard. The chromatogram obtained from the cell extract from Eel Pond is shown in Fig. 4.

A precursor ion scan for $m / z 751$ and 765 was used to screen for diol-esters that would be expected to fragment in a similar manner as OA-D8 and DTX1-D7. These fragments, corresponding to $\left[\mathrm{M}-3 \mathrm{H}_{2} \mathrm{O}\right]^{+}$of OA and DTX1, were predominantly produced from OA, DTX1, and their related diol-esters (Figs. 2 and 3). The precursor ion scan of $m / z 751$ allowed for the detection of OA and OA-D8 (Fig. 5). The MS/ MS spectra of OA and OA-D8 are shown in Fig. 6a and b, respectively. The base peak of $\mathrm{OA}$ was its protonated molecule, while that of OA-D8 was its ammonium adduct. The MS spectra confirmed that OA and OA-D8 were the main toxins present in the sample. The precursor ion scan of $m / z 765$ allowed for the detection of DTX1 and DTX1-D7 (Fig. 7). As with OA and its diol-ester, the base peak of DTX1 was its protonated molecule while that of DTX-D7 was its ammonium adduct (Fig. 8a,b). DTX-D7 was confirmed as the predominant diol-ester of DTX1 in Dinophysis from Eel

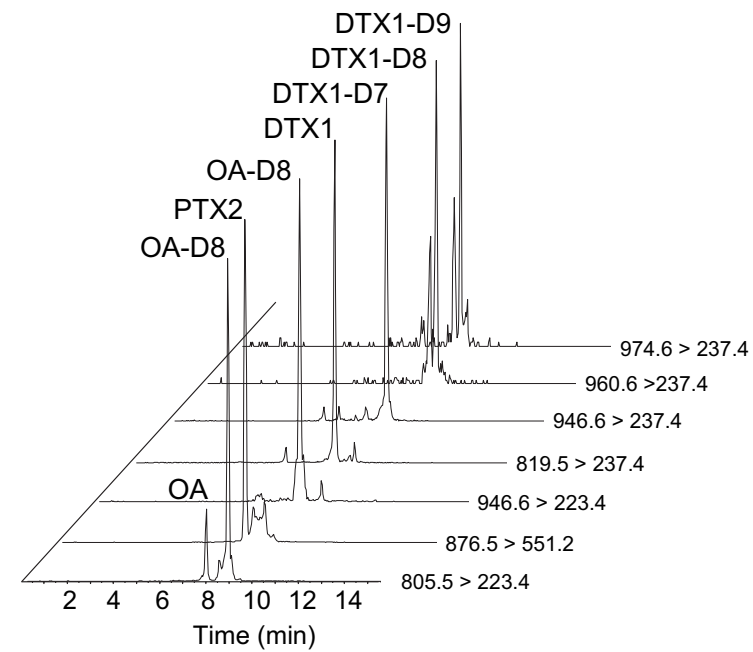

Fig. 4. LC-MS/MS (SRM) determination of OA, DTX1, and their diol-esters, and PTX2 in D. acuminata cells from Eel Pond.

Pond. Both full scan analyses and SRM for DTX4, 5a, 5b and $5 c$ did not show the presence of any of the sulfate derivative.

\subsubsection{Dinophysis strain isolated from Aransas Bay}

The cells and the media from the Dinophysis isolate from Aransas Bay, Texas (DAPA01) were screened for OA, DTX1, their related diol-esters and sulfated analogues, and for PTX2. OA was the only toxin detected and was present in both cells and media.

\subsubsection{D. acuminata isolated from the Bay of Fundy}

The cells of $D$. acuminata from the Bay of Fundy did not contain OA or OA diol-esters. Analysis of the culture medium revealed only trace amounts of OA. DTX1 was detected in both cells and medium but no other peaks were

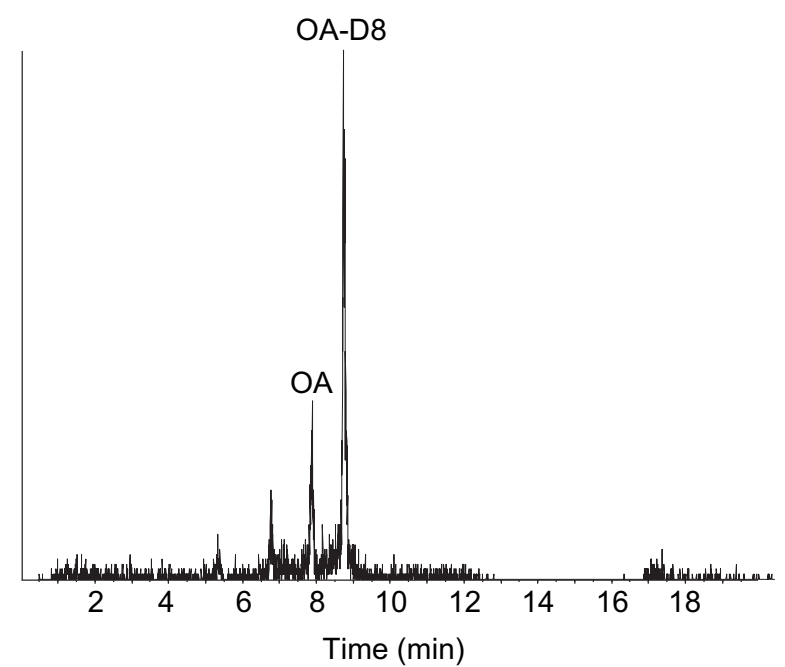

Fig. 5. Reconstructed ion chromatogram of the precursor ion scan of $m / z$ 751. 

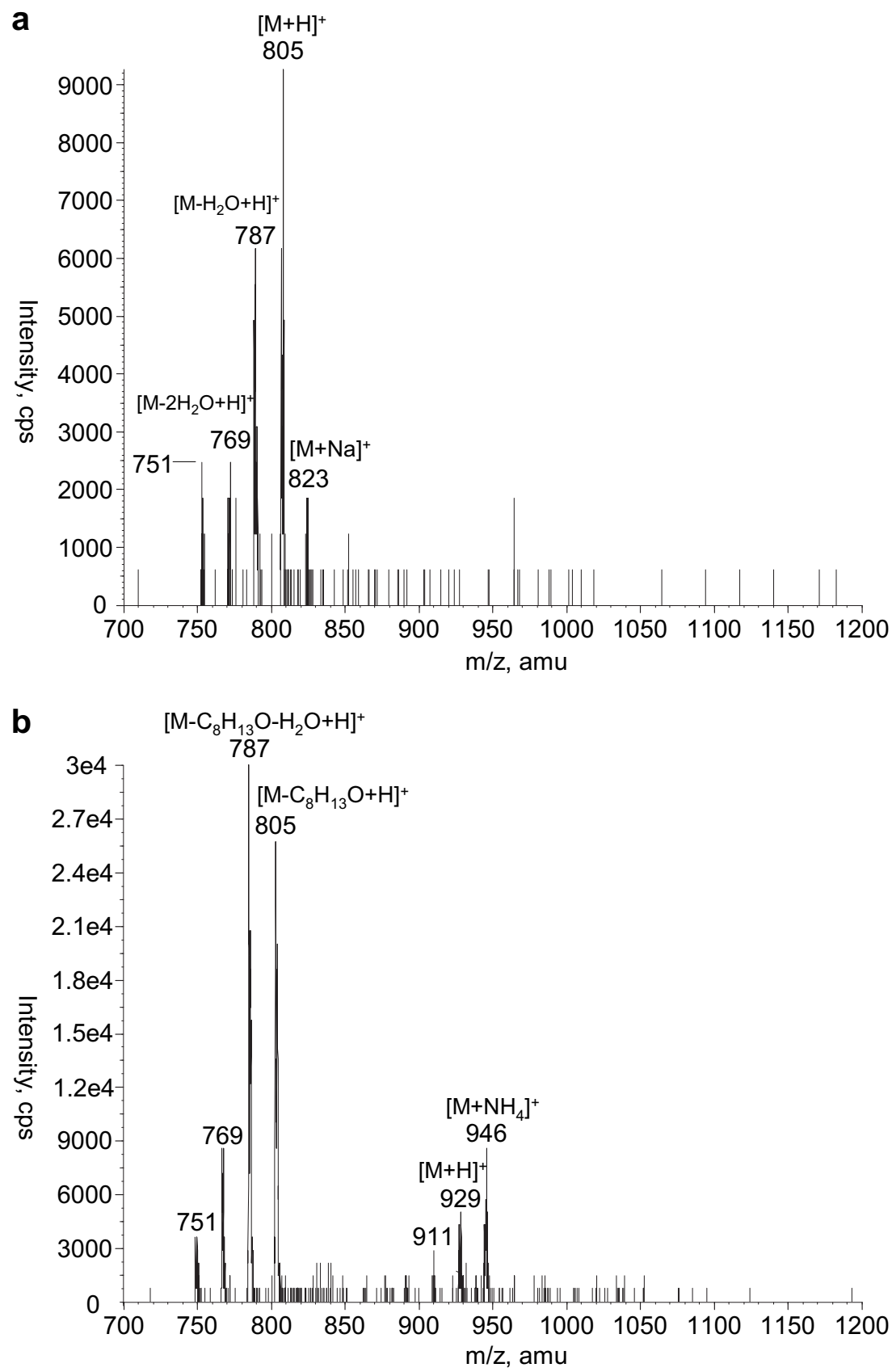

Fig. 6. Mass spectra of the precursor ion scan of the fragment of $m / z 751$, corresponding to: (a) OA ( $M=804 \mathrm{Da})$, and (b) OA-D8 ( $M=928 \mathrm{Da})$.

observed in the DTX1 trace. PTX2 was found in both cells and medium.

\subsubsection{D. acuminata isolated from Martha's Vineyard}

The cells and culture media of $D$. acuminata isolated from Martha's Vineyard, MA, exhibited a similar toxin profile to that of $D$. acuminata from Eel Pond. OA, DTX1, DTX1-D7, and PTX2 were detected in both cells and medium. However, OA-D8 and the putative DTX1-D8 and DTX1-D9 were not detected, possibly due to the lower amount of toxins in the isolate.
3.2.5. Dinophysis strain isolated from Reloncavi Estuary

The cells and the media of the Dinophysis isolate from Reloncavi Estuary, Chile were screened for OA, DTX1, their related diol-esters and sulfated derivatives, as well as PTX2. PTX2 was the only compound detected, and was present in the cells and in the media.

\section{Discussion}

In previous studies, we demonstrated that $D$. acuminata from Eel Pond in Woods Hole, MA, produced toxins of the 


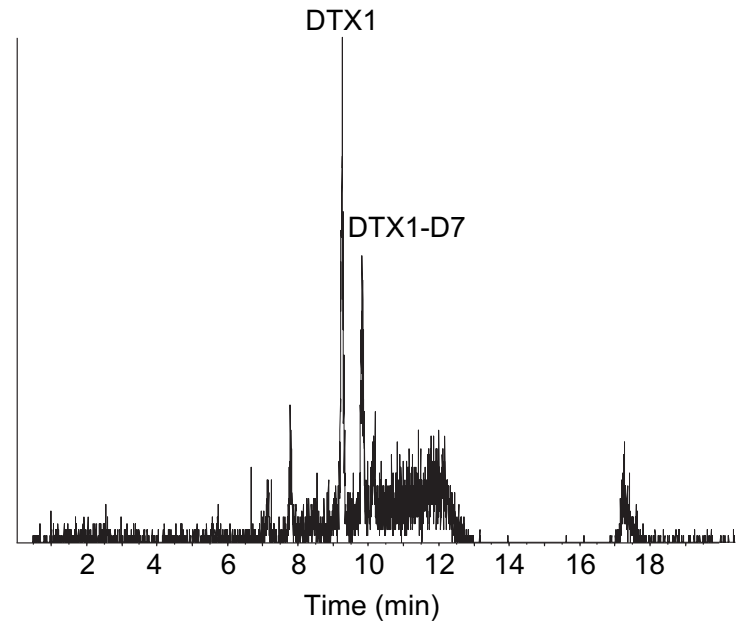

Fig. 7. Reconstructed ion chromatogram of the precursor ion scan of $m / z$ 765.

OA and PTX groups in culture (Hackett et al., 2009) and also showed that toxin production and intracellular quotas varied with growth stage and possibly environmental stress (Tong et al., in press). In the present study, we compared the toxin-producing strain from Eel Pond to four other strains isolated from North and South America. Qualitative results are presented for intracellular and extracellular toxin profiles of these isolates in cultures maintained and sampled under the same conditions.

Toxins were detected in all Dinophysis isolates. Each had a different profile, but isolates from Eel Pond, Martha's Vineyard, and Bay of Fundy were most similar in that they all contained OA, DTX1 and PTX2. Several toxins were identified in D. acuminata from Eel Pond, including OA, OAD8, DTX1, DTX1-D7, and PTX2. In addition, low levels of DTX1-D8 and DTX1-D9 were detected, but not confirmed structurally. The analysis of $D$. acuminata from the coastal waters of Martha's Vineyard revealed a simpler toxin composition, with the presence of OA, DTX1, PTX2 and DTX-D7 in both the cells and the culture medium. D. acuminata from the Bay of Fundy produced DTX1, found in both cells and culture medium, with only trace amounts of $\mathrm{OA}$ in the medium.

The systematic presence of PTX2 in D. acuminata was in general agreement with the literature (Table 2). The only exception is the initial study from Lee et al. (1989) where PTX2 was not detected in D. acuminata from Japan and from France, which may have been due to the lack of sensitivity of the LC-UV method employed. OA and DTX1 analyses of $D$. acuminata from various locations around the world demonstrate that some strains produce both toxins (MacKenzie et al., 2005), in varying relative abundances, while others produce only one or the other (Lee et al., 1989; Fernández et al., 2001; Marcaillou et al., 2001; Miles et al., 2004b; Kamiyama and Suzuki, 2008).

The isolates of Dinophysis from Reloncavi Estuary, Chile, and from Port Aransas, Texas, were different from the three northern strains in that they did not contain OA or DTX1 diol-esters. The toxin profile of the Chile isolate was in accordance with the toxin profile of $D$. acuminata from Chile as reported by Blanco et al. (2007). In the latter study, the LC-MS/MS analysis of net-haul samples revealed the presence of PTX2, while OA, DTXs, and their diol-esters were not detected. Since neither taxonomic nor DNA sequence analysis was conducted on the populations examined by Blanco et al. (2007), their species designation remains open to question. Similarly, our results from the Port Aransas isolate were in accordance with the toxin profile observed in shellfish and in seawater following the bloom in the Gulf of Mexico (Texas) in 2008 (Campbell et al., 2010). OA was found in seawater, but not DTX1, DTX2 and PTX2 (Deeds et al., 2010). Oyster samples collected during and after the bloom contained OA and 7$\mathrm{O}$-acyl esters derivatives of $\mathrm{OA}$ as a result of bio-transformation, while DTX1, DTX2, and their respective ester derivatives were not found. The accumulation of DSP toxins in shellfish from the Gulf of Mexico in 2008 was associated with the occurrence of $D$. cf. ovum (Campbell et al., 2010; Swanson et al., 2010). D. ovum belongs to the D. acuminata complex and its morphology often leads to a misidentification of the species as $D$. acuminata. A bloom of $D$. ovum was reported in the Galician Rias Baixas in Spain and the toxin profile of the strain is the same as that of $D$. ovum from the U.S. (Raho et al., 2008). The absence of PTX2 in a toxin-producing Dinophysis strain is unusual. Indeed, PTX2 has been detected in isolated cells of $D$. acuminata, $D$. acuta, D. fortii, Dinophysis norvegica, and Dinophysis rotundata, all known producers of OA and/or DTXs (Lee et al., 1989; Miles et al., 2004b; Puente et al., 2004).

The presence of OA-D8 in D. acuminata from Eel Pond was confirmed in our previous study (Hackett et al., 2009). The occurrence of OA-D8 in Dinophysis species was first reported in D. acuta from New Zealand (Miles et al., 2004a; Suzuki et al., 2004). Analysis by LC-MS and LC with a diode array detector (DAD) established that the predominant homologue was the trans-C8 OA diol-ester (Suzuki et al., 2004). In addition, two isomers were detected by LC-MS/ MS with retention times slightly longer than OA-D8, but were not unambiguously identified (Suzuki et al., 2004). The occurrence of the cis-OA-D8 in D. acuta from New Zealand was reported later (Miles et al., 2006). Several studies have investigated the presence of ester derivatives of OA and DTX1 in D. acuminata cells using a hydrolysis step to convert the esters to the parent toxins OA and DTX1 (Yasumoto et al., 1985).

D. acuminata from New Zealand contained both $\mathrm{OA}$ and DTX1 but none of the corresponding esters (MacKenzie et al., 2005). In France and Spain several samples of $D$. acuminata were analyzed for OA and DTX1. Only OA was detected in the samples as well as non-characterized esters of OA (Fernandez et al., 2003; Marcaillou et al., 2005). In Chilean field populations, neither OA nor DTX1 were detected before or after hydrolysis (Blanco et al., 2007). A summary of the $D$. acuminata toxin profiles reported in the literature is presented in Table 2.

Two studies have reported the existence of diol-esters of DTX1, both relying on MS/MS data of $P$. lima extracts (Morton et al., 2009; Vale and Sampayo, 2002). The presence of DTX1-D8 was proposed after the detection of a compound in the transition windows $960.7 \rightarrow 237.1$ and 
a
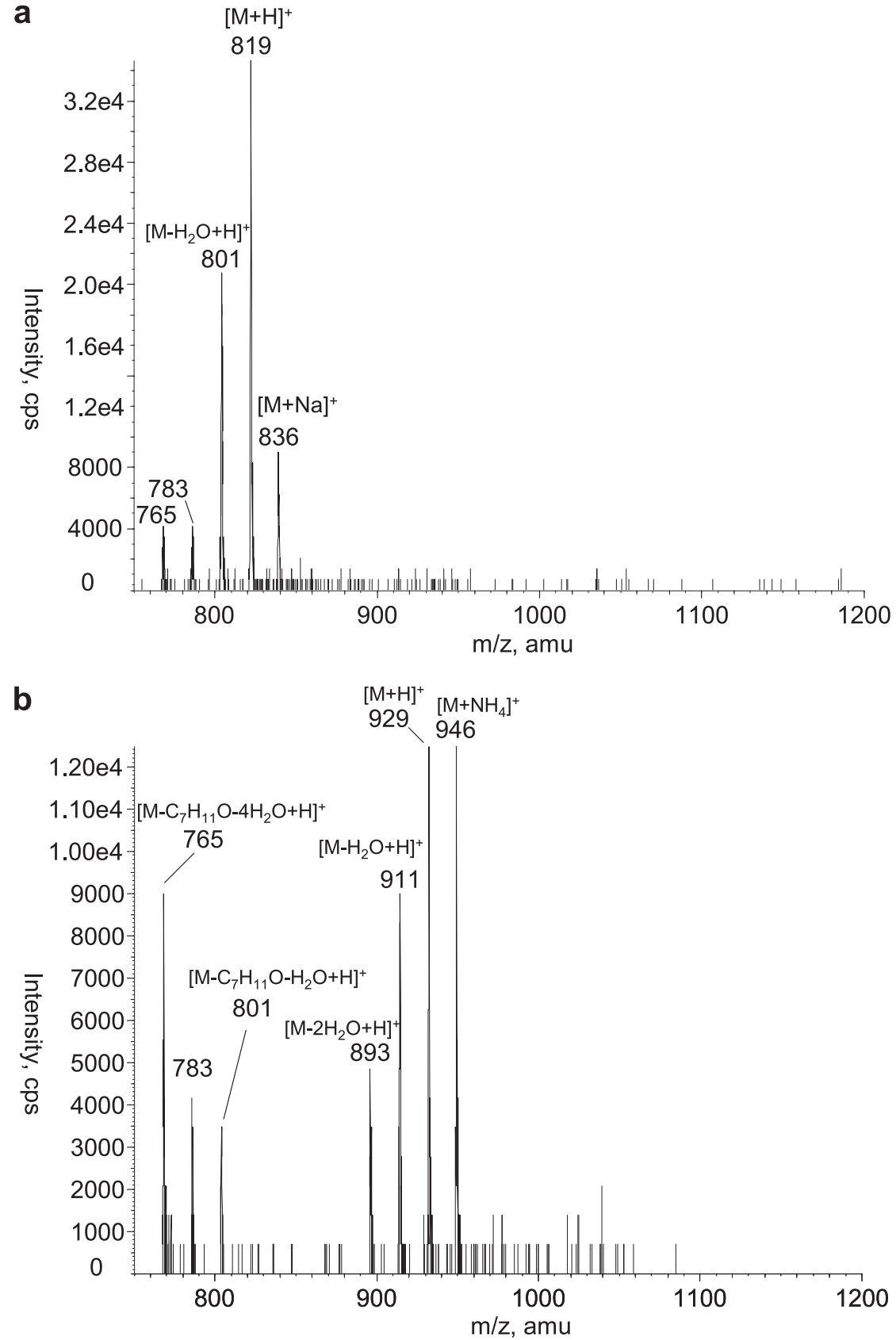

Fig. 8. Mass spectra of the precursor ion scan of the fragment of $m / z 765$ corresponding to: (a) DTX1 $(M=818 \mathrm{Da})$, and (b) DTX1-D7 ( $M=928$ Da).

$960.7 \rightarrow 765.6$ in P. lima cells collected in the Black Sea (Morton et al., 2009). The optimum transitions for the detection of the diol-ester of OA and DTX1 found in this study were the same as those used by Morton and coworkers. The ammonium adduct of the diol-esters were selected as the precursor ion and the ion of $m / z 237$ as the fragment. We found that when low collision energy was used, the fragment of $m / z 765.6$ corresponding to the loss of the diol-ester chain as well as four losses of water was very abundant. The identical choices of the pseudo-molecular ions and of the fragment ions are not surprising since both studies used the same LC-MS system (API 4000). Vale and Sampayo (2002) used a single quadrupole MS for the detection of DTX1 diol-esters in P. lima collected on the Portuguese coast. The presence of DTX1-D8 and DTX1-D9 was proposed based on the detection by single-ion monitoring of the sodium and potassium adduct of both compounds. In our study, we found strong evidence based on MS/MS fragmentation data of the presence of DTX1-D7 in D. acuminata isolates from Eel Pond and Martha's Vineyard. However, our data did not allow for the establishment of the positions of the unsaturated bonds. 
Table 2

Literature review of the reported DSP toxins detected in Dinophysis acuminata ${ }^{\text {a }}$ from various geographical locations.

\begin{tabular}{|c|c|c|c|c|c|}
\hline Origin & Reference & $\mathrm{OA}$ & DTX1 & OA diol-esters & PTX2 \\
\hline Japan & Lee et al., 1989 & $\operatorname{tr}$ & $\mathrm{p}$ & - & nd \\
\hline France & Lee et al., 1989 & $\mathrm{p}$ & - & - & nd \\
\hline Canada & Cembella, 1989 & $\mathrm{p}$ & - & - & - \\
\hline Japan & Yasumoto, 1990 & $\mathrm{p}$ & - & - & - \\
\hline Spain & Blanco et al., 1995 & $\mathrm{p}$ & - & - & - \\
\hline Sweden & Johansson et al., 1996 & $\mathrm{p}$ & nd-tr & - & - \\
\hline Denmark & Andersen et al., 1996 & nd-p & - & - & - \\
\hline Spain & Fernández et al., 2001 & $\mathrm{p}$ & - & - & - \\
\hline France & Marcaillou et al., 2001 & $\mathrm{p}$ & nd & - & - \\
\hline France & Mondeguer et al., 2002 & $\mathrm{p}$ & nd & - & - \\
\hline Portugal & Vale and Sampayo, 2002 & $\mathrm{p}$ & nd & - & $\mathrm{p}$ \\
\hline Spain & Morono et al., 2003 & nd-p & nd & nd-p & - \\
\hline Norway & Miles et al., 2004b & nd-p & nd & nd & $\mathrm{p}$ \\
\hline France & Marcaillou et al., 2005 & nd-p & nd & nd-p & - \\
\hline New Zealand & MacKenzie et al., 2005 & $\mathrm{tr}-\mathrm{p}$ & $\mathrm{p}$ & nd & $\mathrm{p}$ \\
\hline Chile & Blanco et al., 2007 & nd & nd & nd & $\mathrm{p}$ \\
\hline Japan & Suzuki et al., 2008 & nd & nd-p & - & $\mathrm{p}$ \\
\hline Japan & Kamiyama and Suzuki, 2008 & nd & $\mathrm{p}$ & - & $\mathrm{p}$ \\
\hline
\end{tabular}

Tr: trace amount, nd: not detected, p: present, -: not included in analysis.

a Note that $D$. ovum belongs to the $D$. acuminata complex and its morphology often leads to a misidentification of the species as $D$. acuminata.

Studies on the production of toxins in $P$. lima cultures over a 90-day period demonstrated that $\mathrm{OA}$ is either solely or partially due to enzymatic hydrolysis of DTX4 (Quilliam et al., 1996). This was based on the discovery of high intracellular DTX4 concentration with only low concentrations of OA and DTX1 in boiled extracts, where enzymatic activity was stopped. Since OA was found to be the predominant toxin in the culture medium, followed by DTX1 and DTX4 in trace amounts, it was suggested that OA could be produced in the cell in low amount similar to DTX1. The majority of OA found in the medium would be the result of a very fast enzymatic hydrolysis of DTX4 to OA diol-ester derivatives, which are further hydrolysed at a lower rate to yield OA. We investigated whether toxin production from our Dinophysis cultures are mediated though the same mechanism. Thus, the Dinophysis cells were boiled after collection to stop enzymatic activity and the extracts were screened for DTX4, DTX5a, b and c. None of the cultures contained the sulfated esters. This suggests that the known sulfated esters are not involved in the production of OA and DTX1, or that hydrolysis of sulfated esters occurred in the filtration process, despite the extreme care with which the samples were handled.

DNA analysis determined that all five isolates belonged to the $D$. acuminata complex, with two major geographic subgroups, as was also seen with the toxin profiles. The three more northern strains were conclusively identified as $D$. acuminata, while the two more southern strains matched closely with both $D$. acuminata and D. ovum. Results obtained from the DNA analysis matched previous reports in the literature. Hackett et al. (2009) found the isolate from Woods Hole, MA, to be $D$. acuminata using another gene, the SSU rDNA gene. Campbell et al. (2010) identified an isolate collected at a similar location (Gulf of Mexico, TX) and time (February-March, 2008) as being D. cf. ovum F. Schütt. While we could not definitively identify our Texas strain as being $D$. ovum, the toxin profile was the same as that presented by Campbell et al. and matched both $D$. ovum and D. acuminata in GenBank. The identity of our other three strains was not previously reported. Work is underway to confirm the species identification of all five strains using light and scanning electron microscopy.

\section{Conclusions}

Toxin profiles of Dinophysis species isolated from various geographical regions of North and South America were established. All strains were cultured under the same conditions and harvested at the same growth stage. The production of PTX2, OA, DTX1, OA-D8, and DTX-D7 by Dinophysis was demonstrated. The presence of OA or DTX1 was not systematically associated with the presence of their diol-ester derivatives. Cells and the culture medium generally exhibited the same toxin composition. The toxin compositions of the three northern strains were similar, with the production of OA, DTX1, and PTX2. In addition, ester derivatives (OA-D8 and DTX1-D7) were also detected in some of the strains. The Dinophysis strain from the Gulf of Mexico only produced OA, while the one from Chile only produced PTX2. These findings should assist with hazard identification in existing or future DSP toxin monitoring programs. They also highlight important scientific questions that need to be addressed, including the genetic, physiological, and nutritional factors influencing toxin composition and content of Dinophysis.

\section{Acknowledgements}

Funding was provided by NSF Grant OCE-0850421, the Ocean Life Institute and the Coastal Ocean Institute at the Woods Hole Oceanographic Institution, and the Woods Hole Center for Oceans and Human Health through NSF grant OCE-0430724 and NIEHS grant 1 P50 ES012742. MMT would like to thank the Ministry of Education, People's Republic of China for financial support as a Grand Fostering Project (No. 707011) and the China Scholarship Council. This project was supported in part by an appointment to 
the Research Participation Program administered by the Oak Ridge Institute for Science and Education through an agreement with the for the Food and Drug Administration. We also thank Dr. Jeremiah D. Hackett (Department of Ecology and Evolutionary Biology, University of Arizona, USA) who helped in the isolation of Dinophysis and Dr. Christopher Miles (Norway's National Veterinary Institute) and Dr. Michael Quilliam (NRC - Canada) for their generous gifts of PTX11 and OA-D8, respectively. We also would like to thank Deana L Erdner from the University of Texas Marine Science Institute, Port Aransas, for supplying the isolate from this location as well as Dave Kulis (Woods Hole Oceanographic Institution) for collecting the samples from the Bay of Fundy. Thanks to Dr. Steve Plakas from the FDA, Gulf Coast Seafood laboratory, Dauphin Island, USA, for his very valuable comments on this manuscript.

\section{Conflict of interest}

None.

\section{References}

Andersen, P., Hald, B., Emsholm, 1996. Toxicity of Dinophysis acuminata in Danish coastal waters. In: Yasumoto, Oshima, Fukuyo (Eds.), Harmful and Toxic Algal Blooms, pp. 281-284.

Anderson, D.M., Kulis, D.M., Doucette, G.J., Gallagher, J.C., Balech, E., 1994 Biogeography of toxic dinoflagellates in the genus Alexandrium from the northeastern United States and Canada. Marine Biology 120 (3), 467-478.

Anonymous, 2008. Opinion of the scientific panel in contaminants in the food chain on a request from the European Commission on marine biotoxins in shellfish - okadaic acid and analogues. EFSA 589, 1-62.

Aune, T., 1997. Health effects associated with algal toxins from seafood. Arch. Toxicol. Suppl. 19, 389-397.

Blanco, J., Fernández, M., Mariño, J., Reguera, B., Míguez, A., Maneiro, J., Cacho, E., Martínez, A., 1995. From Dinophysis spp. toxicity to DSP outbreaks: a preliminary model of toxin accumulation in mussels. In: Lassus, Arzul, Erard, Gentien, Marcaillou (Eds.), Harmful Marine Algal Blooms, pp. 777-782.

Blanco, J., Alvarez, G., Uribe, E., 2007. Identification of pectenotoxins in plankton, filter feeders, and isolated cells of a Dinophysis acuminate with an atypical toxin profile, from Chile. Toxicon 49, 710-716.

Boni, L., Milandri, A., Poletti, R., Pompei, M., 1993. DSP cases along the coast of Emilia-Romagna (Northwestern Adriatic Sea). In: Smayda Shimizu (Eds.), Toxic Phytoplankton Blooms in the Sea, pp. 475-481.

Campbell, L., Olson, R.J., Sosik, H.M., Abraham, A., Henrichs, D.W., Hyatt, C. J., Buskey, E.J., 2010. First harmful Dinophysis (Dinophyceae, Dinophysiales) bloom in the US is revealed by automated imaging flow cytometry. J. Phycol. 46, 66-75.

Cembella, A., 1989. Occurrence of okadaic acid, a major diarrheic shellfish toxin, in natural populations of Dinophysis spp. from the eastern coast of North America. J. Appl. Phycol. 1, 307-310.

Cruz, P.G., Daranas, A.H., Fernandez, J.J., Souto, M.L., Norte, M., 2006. DTX5c, a new OA sulphate ester derivative from cultures of Prorocentrum belizeanum. Toxicon 47, 920-924.

Deeds, J.R., Wiles, K., Heideman, G., White, K., Abraham, A., 2010. First U.S report of shellfish harvesting closures due to confirmed okadaic acid in Texas Gulf coast oysters. Toxicon 55, 1138-1146.

Edvardsen, B., Shalchian-Tabrizi, K., Jakobsen, K.S., Medlin, L.K., Dahl, E., Brubak, S., Paasche, E., 2003. Genetic variability and molecular phylogeny of Dinophysis species (Dinophyceae) from Norwegian waters inferred from single cell analyses of rDNA. J. Phycol. 39, 395408 .

Fernández, M.L., Reguera, B., Ramilo, I., Martinez, A., 2001. Toxin content of Dinophysis acuminata, D. acuta and D. caudata from the Galician Rías Baixas. In: Hallegraeff, G.M. (Ed.), Harmful Algal Blooms, pp. 360363. 2000.

Fernandez, J.J., Suarez-Gomez, B., Souto, M.L., Norte, M., 2003. Identification of new okadaic acid ester derivatives from laboratory cultures of Prorocentrum lima. J. Nat. Prod. 66, 1294-1296.
Fux, E., Bire, R., Hess, P., 2009. Comparative accumulation and composition of lipophilic marine biotoxins in passive samplers and in mussels (M. edulis) on the West Coast of Ireland. Harmful Algae 8, 523-537.

Gago-Martinez, A., Fuente Santiago, E., Rodriguez Vazquez, J., Alvito, P., Sousa, I., 1993. Okadaic acid as the main component of diarrhetic shellfish toxins in molluscs from the west coast of Spain and Portugal. In: Smayda, Shimizu (Eds.), Toxic Phytoplankton Blooms in the Sea, pp. 537-540.

Garcia, C., Gonzalez, V., Cornejo, C., Palma-Fleming, H., Lagos, N., 2004. First evidence of dinophysistoxin-1 ester and carcinogenic polycyclic aromatic hydrocarbons in smoked bivalves collected in the Patagonia fjords. Toxicon 43, 121-131.

Hackett, J.D., Tong, M., Kulis, D.M., Fux, E., Hess, P., Bire, R., Anderson, D.M., 2009. DSP toxin production de novo in cultures of Dinophysis acuminata (Dinophyceae) from North America. Harmful Algae 8, 873-879.

Hu, T., Marr, J., de Freitas, A.S.W., Quilliam, M.A., Walter, J.A., Wright, J.L.C., Pleasance, S., 1992a. New diol-esters of okadaic acid isolated from cultures of the dinoflagellates Prorocentrum lima and Prorocentrum concavum. J. Nat. Prod. 55, 1631-1637.

Hu, T., Doyle, J., Jackson, D., Marr, J., Nixon, E., Pleasance, S., Quilliam, M., Walter, J., Wright, J., 1992b. Isolation of a new diarrhetic shellfish from Irish mussels. J. Chem. Soc. 30, 39-41.

Hu, T., Curtis, J.M., Walter, J.A., McLachlan, J.L., Wright, J.L.C., 1995a. Two new water-soluble DSP toxin derivatives from Prorocentrum maculosum: possible storage and excretion products of the dinoflagellate. Tetrahedron Lett. 36, 9273-9276.

Hu, T., Curtis, J.M., Walter, J.A., Wright, J.L.C., 1995b. Identification of DTX4 , a new water-soluble phosphatase inhibitor from the toxic dinoflagellate Prorocentrum lima. J. Chem. Soc., 597-599.

Johansson, N., Graneli, E., Yasumoto, T., Carlsson, P., Legrand, C., 1996. Toxin production by Dinophysis acuminata and $D$. acuta cells grown under nutrient sufficient and deficient conditions. In: Harmful and Toxic Algal Blooms, pp. 277-280.

Kamiyama, T., Suzuki, T., 2008. Production of dinophysistoxin-1 and pectenotoxin-2 by a culture of Dinophysis acuminata (Dinophyceae). Harmful Algae 8, 312-317.

Larsen, K., Petersen, D., Wilkins, A.L., Samdal, I.A., Sandvik, M. Rundberget, T., Goldstone, D., Arcus, V., Hovgaard, P., Rise, F, Rehmann, N., Hess, P., Miles, C.O., 2007. Clarification of the C-35 stereochemistries of dinophysistoxin-1 and dinophysistoxin-2 and its consequences for binding to protein phosphatase. Chem. Res. Toxicol. $20,868-875$

Lee, J., Igarashi, T., Fraga, S., Dahl, E., Hovgaard, P., Yasumoto, T., 1989. Determination of diarrhetic shellfish toxins in various dinoflagellate species. J. Appl. Phycol. 1, 147-152.

Lin, S., Zhang, H., Spencer, D., Norman, J., Gray, M., 2002. Widespread and extensive editing of mitochondrial mRNAS in dinoflagellates. J. Mol. Biol. 320, 727-739.

MacKenzie, L., Truman, P., Satake, M., Yasumoto, T., Adamson, J., Mountfort, D., White, D., 1998. Dinoflagellate blooms and associated DSP-toxicity in shellfish in New Zealand. In: Reguera, Blanco, Fernandez, Wyatt (Eds.), Harmful Algae. Xunta de Galicia and Intergovernmental Oceaonographic commission of UNESCO, pp. 74-77.

MacKenzie, L., Holland, P., McNabb, P., Beuzenberg, V., Selwood, A., Suzuki, T., 2002. Complex toxin profiles in phytoplankton and Greenshell mussels (Perna canaliculus), revealed by LC-MS/MS analysis. Toxicon 40, 1321-1330.

MacKenzie, L., Beuzenberg, V., Holland, P., McNabb, P., Suzuki, T.S.A., 2005. Pectenotoxin and okadaic acid-based toxin profiles in Dinophysis acuta and Dinophysis acuminata from New Zealand. Harmful Algae 4, 75-85.

Madigan, T.L., Lee, K.G., Padula, D.J., McNabb, P., Pointon, A.M., 2006. Diarrhetic shellfish poisoning (DSP) toxins in South Australian shellfish. Harmful Algae 5, 119-123.

Mak, K., Yu, H., Choi, M.C., Shen, X., Lam, M.H.W., Martin, M., Wu, R.S.S., Wong, P.S., Richardson, B.J., Lam, P.K.S., 2005. Okadaic acid, a causative toxin of diarrhetic shellfish poisoning, in green-lipped mussels Perna viridis from Hong Kong fish culture zones: method development and monitoring. Mar. Pollut. Bull. 51, 1010-1017. 4th International Conference on Marine Pollution and Ecotoxicology.

Marcaillou, C., Gentien, P., Lunven, M., Le grand, J., Mondeguer, F., Danielou, M.M., Crassous, M.P., Youenou, A., 2001. Dinophysis acuminata distribution and specific toxin content in relation to mussel contamination. In: Harmful Algal Blooms, pp. 356-358. 2000.

Marcaillou, C., Mondeguer, F., Gentien, P., 2005. Contribution to toxicity assessment of Dinophysis acuminata (Dinophyceae). J. Appl. Phycol. 17, $155-160$

Marr, J.C., Hu, T., Pleasance, S., Quilliam, M.A., Wright, J.L.C., 1992. Detection of new 7-O-acyl derivatives of diarrhetic shellfish poisoning 
toxins by liquid chromatography-mass spectrometry. Toxicon 30 , 1621-1630.

Miles, C.O., Wilkins, A.L., Munday, R., Dines, M.H., Hawkes, A.D., Briggs, L. R., Sandvik, M., Jensen, D.J., Cooney, J.M., Holland, P.T., 2004a. Isolation of pectenotoxin-2 from Dinophysis acuta and its conversion to pectenotoxin-2 seco acid, and preliminary assessment of their acute toxicities. Toxicon $43,1-9$.

Miles, C.O., Wilkins, A.L., Samdal, I.A., Sandvik, M., Petersen, D., Quilliam, M.A., Naustvoll, L.J., Rundberget, T., Torgersen, T., Hovgaard, P., Jensen, D.J., Cooney, J.M., 2004b. A Novel pectenotoxin, PTX-12, in Dinophysis spp. and shellfish from Norway. Chem. Res. Toxicol. 17, 1423-1433.

Miles, C.O., Wilkins, A.L., Hawkes, A.D., Jensen, D.J., Cooney, J.M., Larsen, K., Petersen, D., Rise, F., Beuzenberg, V., Lincoln MacKenzie, A., 2006. Isolation and identification of a cis-C8-diol-ester of okadaic acid from Dinophysis acuta in New Zealand. Toxicon 48, 195-203.

Miles, C.O., 2007. Pectenotoxins. In: Botana, L. (Ed.), Phycotoxins: Chemistry and Biochemistry. Blackwell Publishing, pp. 159-186.

Mondeguer, F., Nezan, E., Rocher, G., Marcaillou, C., Sechet, V., 2002. Aspect and toxicity of Dinophysis acuminata associated. In: Steidinger, Landsberg, Toma, Vargo (Eds.) Poster at the Xth International Conference on Harmful Algae.

Morono, A., Arevalo, F., Fernandez, M.L., Maneiro, J., Pazos, Y., Salgado, C., Blanco, J., 2003. Accumulation and transformation of DSP toxins in mussels Mytilus galloprovincialis during a toxic episode caused by Dinophysis acuminata. Aquat. Toxicol. 62, 269-280.

Morton, S.L., Vershinin, A., Smith, L.L., Leighfield, T.A., Pankov, S., Quilliam, M.A., 2009. Seasonality of Dinophysis spp. and Prorocentrum lima in Black Sea phytoplankton and associated shellfish toxicity. Harmful Algae 8, 629-636.

Mouratidou, T., Kaniou-Grigoriadou, I., Samara, C., Kouimtzis, T., 2006. Detection of the marine toxin okadaic acid in mussels during a diarrhetic shellfish poisoning (DSP) episode in Thermaikos Gulf, Greece, using biological, chemical and immunological methods. Sci. Total Environ. 366, 894-904.

Murata, M., Shimatani, S.M., Sugitani, H., Oshima, Y., Yasumoto, T., 1982. Isolation and structural elucidation of the causative toxin of the diarrhetic shellfish poisoning. B. Jpn. Soc. Sci. Fish. 48, 549-552.

Norte, M., Padilla, A., Fernández, J., 1994. Studies on the biosynthesis of the polyether marine toxin dinophysistoxin-1 (DTX-1). Tetrahedron Lett. $35,1441-1444$

Park, M.G., Kim, S., Kim, H.S., Myung, G., Kang, Y.G., Yih, W., 2006. First successful culture of the marine dinoflagellate Dinophysis acuminata. Aquat. Microb. Ecol. 45, 101-106.

Puente, P.F., Saez, M.J.F., Hamilton, B., Lehane, M., Ramstad, H., Furey, A., James, K.J., 2004. Rapid determination of polyether marine toxins using liquid chromatography-multiple tandem mass spectrometry. J. Chrom. A 1056, 77-82.

Quilliam, M., 1995. Analysis of diarrhetic shellfish poisoning toxin in shellfish tissue by liquid chromatoigraphy with fluorimetric and mass spectrometric detection. J. AOAC Intl. 78, 555-570.

Quilliam, M.A., Hardstaff, W.R., Ishida, N., McLachlan, J.L., Reeves, A.R., Ross, N.W., Windust, A.J., 1996. Production of diarrhetic shellfish poisoning (DSP) toxins by Prorocentrum lima in culture and development of analytical methods. In: Yasumoto, Oshima, Y., Fukuyo, Y. (Eds.), Harmful and Toxic Algal Blooms. IOC-UNESCO, Paris, pp. 289-292.

Raho, N., Pizarro, G., Escalera, L., Reguera, B., Marin, I., 2008. Morphology, toxin composition and molecular analysis of Dinophysis ovum Schutt, a dinoflagellate of the 'Dinophysis acuminata complex'. Harmful Algae 7, 839-848.

Reguera, B., Bravo, I., Marcaillou-Le Baut, C., Masselin, P., Fernandez, M., Miguez, A., Martinez, A., 1993. Monitoring of Dinophysis spp and vertical distribution of okadaic acid on mussel rafts in Ria de
Pontevedra (NW Spain). In: Smayda, Shimizu (Eds.), Toxic Phytoplankton Blooms in the Sea, pp. 553-558.

Suarez-Gomez, B., Souto, M.L., Norte, M., Fernandez, J.J., 2001. Isolation and structural determination of DTX-6, a new okadaic acid derivative. J. Nat. Prod. 64, 1363-1364.

Suarez-Gomez, B., Souto, M.L., Cruz, P.G., Fernandez, J.J., Norte, M., 2005. New targets in diarrhetic shellfish poisoning control. J. Nat. Prod. 68, 596-599.

Subba Rao, D., Pan, Y., Zitko, V., Mackeigan, K., 1993. Diarrhetic shellfish poisoning (DSP) associated with subsurface bloom of Dinophysis norvegica in Bedford Basin, eastern Canada. Mar. Ecol. Prog. Ser. 97, $117-126$.

Suzuki, T., Beuzenberg, V., MacKenzie, L., Quilliam, M.A., 2004. Discovery of okadaic acid esters in the toxic dinoflagellate Dinophysis acuta from New Zealand using liquid chromatography/tandem mass spectrometry. Rapid Commun. Mass Sp. 18, 1131-1138.

Suzuki, T., Miyazono, A., Baba, K., Sugawara, R., Kamiyama, T., 2008. LCMS/MS analysis of okadaic acid analogues and other lipophilic toxins in single-cell isolates of several Dinophysis species collected in Hokkaido, Japan. Harmful Algae 8, 233-238.

Swanson, K.M., Flewelling, L.J., Byrd, M., Nunez, A., Villareal, T.A., 2010. The 2008 Texas Dinophysis ovum bloom: distribution and toxicity. Harmful Algae 9, 190-199.

Tachibana, K., Scheuer, P.J., 1981. Okadaic acid, a cytotoxic polyether from two marine sponges of the genus Halichondria. J. Am. Chem. Soc. 103, 2469-2471.

Tong, M., Kulis, D., Fux, E., Smith, J.L., Hess, P., Zhou, Q., Anderson, D. The effects of growth phase and light intensity on toxin production by Dinophysis acuminata from the northeastern United States. Harmful Algae (doi:10.1016/j.hal.2010.10.005), in press.

Torgersen, T., Aasen, J., Aune, T., 2005. Diarrhetic shellfish poisoning by okadaic acid esters from brown crabs (Cancer pagurus) in Norway. Toxicon 46, 572-578.

Torgersen, T., Miles, C.O., Runberget, T., Wilkins, A.L., 2008a. New esters of okadaic acid in seawater and blue mussels (Mytilus edulis). J. Agr. Food Chem. 56, 9628-9635.

Torgersen, T., Sandvik, M., Lundve, B., Lindergarth, S., 2008b. Profiles and levels of fatty acid esters of okadaic acid group toxins and pectenotoxins during toxin depuration. Part II: blue mussels (Mytilus edulis) and flat oyster (Ostrea edulis). Toxicon 52, 418-427.

Turrell, E.A., Stobo, L., 2007. A comparison of the mouse bioassay with liquid chromatography-mass spectrometry for the detection of lipophilic toxins in shellfish from Scottish waters. Toxicon 50, $442-447$.

Vale, P., Sampayo, M.A., 2002. Pectenotoxin-2 seco acid, 7-epi-pectenotoxin-2 seco acid and pectenotoxin-2 in shellfish and plankton from Portugal. Toxicon 40, 979-987.

Windust, A., Quilliam, M., Wright, J., McLachlan, J., 1997. Comparative toxicity of the diarrhetic shellfish poisons, okadaic acid, okadaic acid diol-ester and dinophysistoxin-4, to the diatom Thalassiosira weissflogii. Toxicon 35, 1591-1603.

Yasumoto, T., Oshima, Y., Yamaguchi, M., 1978. B. Jpn. Soc. Sci. Fish., 1249-1255.

Yasumoto, T., Murata, M., Oshima, Y., Sano, M., Matsumoto, G.K., Clardy, J., 1985. Diarrhetic shellfish toxins. Tetrahedron 41, 1019-1025.

Yasumoto, T., Murata, M., Lee, J., Torigoe, K., 1989. Polyether toxins produced by dinoflagellates. In: Natori, Hashimoto, Ueno (Eds.), Mycotoxins and Phycotoxins, 88, pp. 375-382.

Yasumoto, T., 1990. Recent progress in the chemistry of dinoflagellate toxins. In: Granéli, E. (Ed.), Toxic Marine Phytoplankton, pp. 259-270.

Zhao, J., Lembeye, G., Cenci, G., Wall, B., Yasumoto, T., 1993. Determination of okadaic acid and dinophysistoxin-1 in mussels from Chile, Italy and Ireland. In: Smayda, Shimizu (Eds.), Toxic Phytoplankton Blooms in the Sea, pp. 587-592. 